УДК 346.2:336.761(477)

DOI https://doi.org/10.32837/pyuv.v2i3(28).362

\author{
Є. А. Кузнєцова \\ аспірант (ад’юнкт) кафедри фінансового права \\ та фіскального адміністрування \\ Національної академії внутрішніх справ
}

\title{
ПОНЯТТЯ ТА ОЗНАКИ ПРОФЕСІЙНИХ УЧАСНИКІВ РИНКУ ЦІННИХ ПАПЕРІВ В УКРАЇНІ
}

Спостерігаючи динамічні процеси на ринку цінних паперів (далі - РЦП), варто звернути увагу на те, що більшість основних понять у цій сфері взагалі не визначена у законодавстві, відсутня їх уніфікація. Щодо деяких з них не сформульована і наукова точка зору. Правове регулювання процесів, що існують на РЦП, вимагає чіткої регламентації як процедур, так і професійної діяльності. Зміст діяльності професійних учасників РЦП характеризується значною різноманітністю залежно від функцій, які вони виконують, їх повноважень, мети здійснення діяльності. Визначення поняття та ознак професійної діяльності використовується для оптимізації регулятивних процесів на РЦП. Сьогодні збільшення відставання законодавства від практики господарювання на РЦП може стати основним гальмівним чинником у формуванні дієвого, ефективного ринку та у забезпеченні інтеграції до ринків Свропейського Союзу.

Проблема оцінки фінансово-правового регулювання професійних учасників РЦП є новою у вітчизняній літературі, оскільки дослідники, зокрема В.В. Колесник, Ю.М. Лисєнков, О.Г. Мендул, В.С. Торкановський, Н.В. Фетюхіна, І.А. Шевчук, у своїх роботах торкаються лише загальної характеристики правового статусу учасників РЦП.

Окремі аспекти фінансово-правового регулювання професійних учасників РЦП залишаються не дослідженими у правовій науці України. Так, питання створення професійних учасників РЦП H.C. Кузнєцова та I.P. Назарчук розглядали 3 загальних позицій, залишаючи поза увагою суперечливі питання набуття професійним учасником РЦП відповідного статусу та прав юридичної особи. Російські вчені ЖЖ.А. Іонова та В.С. Мартем'янов досліджували теоретичні положення легітимації господарюючих суб'єктів в цілому. Проблема визначення понять фондової біржі та торговельно-інформаційної системи розглядалася частково. Зокрема, Г. Остапович визначала фондову біржу та TIC з позицій саморегуляторних організацій, О. Чуркін характеризував фондову біржу в системі цивільних правовідносин.

Вибір теми статті визначається також тим, що в українській юридичній науці комплексні дослідження фінансово-правового регулювання професійних учасників РЦП не здійснювалися. Зокрема, залишилися поза увагою науковців поняття, ознаки та класифікація професійних учасників РЦП, особливості ліцензування професійної діяльності на РЦП, права та обов'язки професійних учасників РЦП, тому метою даного дослідження $€$ визначення поняття та ознак професійних учасників РЦП.

В Україні, яка активно розвивається шляхом ринкових перетворень, відбувається становлення і послідовний розвиток ринку цінних паперів (фондового ринку). Названий ринок виступає однією 3 важливих складових частин ринкової економіки. Він забезпечує акумуляцію тимчасово вільних коштів та їхній перерозподіл у формі інвестицій на розвиток виробництва і сфери послуг, передбачає встановлення необхідних контактів між суб'єктами господарювання, які мають потребу в таких коштах, і тими суб'єктами, які хотіли б інвестувати надлишковий дохід. Формування в сучасній Україні розвиненого, цивілізованого, ефективного ринку цінних паперів, привабливого для внутрішніх та зовнішніх інвесторів, - найголовніше завдання у цій сфері.

Як законодавча категорія ринок цінних паперів (фондовий ринок) офіційно визначений у ст. 2 Закону України «Про цінні папери та фондовий ринок» від 23 лютого 2006 року як сукупність учасників такого ринку та правовідносин між ними щодо розміщення, обігу та обліку цінних паперів і похідних (деривативів). Дане легальне визначення поняття фондового ринку, попри деяку його неповноту (не відображає відносини із зберігання цінних паперів) та окремі спірні положення (зокрема, щодо одностороннього, вузького трактування теоретичної категорії правових відносин), у цілому вірно визначає даний ринок як системне, об'єктивне, економіко-правове явище суспільного буття в єдності його статичних та динамічних елементів. Статику ринку цінних паперів складають, по-перше самі цінні папери та їх похідні, кожний з видів яких має певну юридичну форму та певний правовий режим існування, i, по-друге, учасники цього ринку з визначеним правовим статусом, зумовленим роллю, яку окремі учасники та відповідні групи учасників відіграють на вказаному ринку. Динаміка ринку цінних паперів полягає у сукупності різноманітних відносин між його учасниками (щодо розміщення, обігу, обліку тощо цінних паперів), які постійно виникають, 
змінюються, припиняються і у своїй множинності утворюють те, що прийнято називати функціонуванням даного ринку.

Коло суб’єктів (учасників) вказаного ринку, визначене ст. 2 Закону України «Про цінні папери та фондовий ринок» від 23 лютого 2006 року, включає такі групи цих суб'єктів: емітентів (у тому числі й іноземних), тобто осіб, що видали неемісійні цінні папери, а також інвесторів в цінні папери, інституційних інвесторів, професійних учасників фондового ринку, об'єднання професійних учасників фондового ринку (у тому числі й саморегуляторні організації професійних учасників фондового ринку).

Надалі у своєму досліджені ми зупинимося на проблемному питанні визначення поняття «професійні учасники РЦП», оскільки на рівні Закону України «Про державне регулювання ринку цінних паперів в Україні» від 30 жовтня 1996 року вони визначаються лише як особи, які здійснюють професійну діяльність на РЦП (абз. 3 ст. 1). У визначенні не наведені кваліфікаційні ознаки зазначених осіб, які надавали б чітке уявлення про особливості цього поняття [3].

Згідно з Законом України «Про цінні папери та фондовий ринок» від 23 лютого 2006 року професійними учасники фондового ринку вважаються юридичні особи, утворені в організаційно-правовій формі акціонерних товариств або товариств 3 обмеженою відповідальністю, які на підставі ліцензії, виданої Національною комісією з цінних паперів та фондового ринку, провадять на фондовому ринку професійну діяльність, види якої визначені законами України, а також Центральним депозитарієм цінних паперів [4].

Як бачимо, поняття професійних учасників ринку цінних паперів було закріплене не на рівні основного закону, що регулює ринок цінних паперів, а на рівні спеціального закону. На нашу думку, це є неправильним підходом законодавця, оскільки ці поняття є різними та мають різне змістовне навантаження. Вважаємо, що поняття професійних учасників ринку цінних паперів має бути закріплене на рівні основного закону, що регулює ринок цінних паперів, оскільки це поняття пов'язане саме з комерційним сектором економіки, а не з державним.

Крім цього, в Законі України «Про цінні папери та фондовий ринок» від 23 лютого 2006 року немає окремого розділу, присвяченого саме професійній діяльності ринку цінних паперів, тому дуже складно виокремити поняття та основні ознаки професійних учасників ринку цінних паперів.

Під час дослідження матеріалу у багатьох наукових працях ми натрапляємо на постійну підміну одного поняття іншим, тобто зазначається поняття «професійні учасники РЦП», а дається визначення таких учасників на фондовому ринку, тому ми доходимо висновку, що в юридичній літературі відсутнє узгоджене розуміння цієї категорії.

Так, А.В. Попова у своєму дисертаційному дослідженні «Правове становище професійних учасників ринку цінних паперів в Україні» визначає, що професійними учасниками РЦП є суб’єкти господарювання, які створені у встановленому законом порядку, здійснюють певний вид (види) професійної діяльності на РЦП на підставі ліцензії ДКЦПФР і володіють спеціальною господарською правосуб'єктністю [8, с. 16]. О.В. Кологойда розглядає професійних учасників ринку цінних паперів в Україні шляхом розподілу їх на фінансових посередників, учасників депозитарної системи, фондові біржі [7, с. 4].

Підтримуючи позицію А.В. Попової в частині того, що професійні учасники РЦП є суб'єктами господарювання, вважаємо, що вони повинні мати такі кваліфікуючі ознаки: 1) безпосереднє здійснення господарської діяльності; 2) створення у встановленому законом порядку; 3) наявність майна, необхідного для здійснення обраної суб’єктом чи покладеної на нього господарської діяльності або керівництва такою діяльністю, що може закріплюватися у різних правових титулах; 4) наявність господарської правосуб'єктності.

3 огляду на визначення суб'єктів господарювання, закріплене в ч. 1 ст. 55 Господарського кодексу України (далі - ГК України) [1], професійні учасники РЦП є учасниками господарських відносин, здійснюють такий вид господарської діяльності, як професійна діяльність на РЦП, реалізуючи при цьому господарську компетенцію (сукупність господарських прав та обов'язків, закріплених у відповідних нормативно-правових актах, що регулюють певний вид професійної діяльності), мають відокремлене майно і несуть відповідальність за своїми зобов'язаннями в межах цього майна, крім випадків, передбачених законодавством.

Згідно з ч. 2 ст. 55 ГК України суб'єктами господарювання є:

- господарські організації, зокрема юридичні особи, створені відповідно до ЦК України, державні, комунальні та інші підприємства, створені відповідно до ГК України, а також інші юридичні особи, які здійснюють господарську діяльність та зареєстровані в установленому законом порядку;

- громадяни України, іноземці та особи без громадянства, які здійснюють господарську діяльність та зареєстровані відповідно до закону як підприємці.

Отже, професійними учасниками РЦП можуть стати як юридичні особи, так і громадяни-підприємці. Однак з огляду на чинне законодавство професійними учасниками РЦП можуть бути лише юридичні особи, а саме:

1) торговцями цінними паперами є господарські товариства, для яких операції з цими папе- 
рами є виключним видом діяльності, та банки. Професійна діяльність з торгівлі цінними паперами включає брокерську діяльність, дилерську діяльність, андеррайтинг, діяльність з управління цінними паперами;

2) компанії з управління активами інституційних інвесторів - це також господарські товариства, які здійснюють відповідну професійну діяльність;

3) депозитарну діяльність на ринку цінних паперів здійснюють прямі учасники Національної депозитарної системи - депозитарії, зберігачі, реєстратори власників іменних цінних паперів. Депозитарії цінних паперів - це юридичні особи, які провадять виключно таку діяльність та можуть здійснювати кліринг і розрахунки за угодами щодо цінних паперів. Реєстраторами власників іменних цінних паперів виступають юридичні особи - суб'єкти підприємницької діяльності, а зберігачами є виключно комерційні банки або торговці цінними паперами;

4) клірингова установа утворюється та функціонує у формі акціонерного товариства. Особа набуває статусу клірингової установи з дня отримання ліцензії на провадження клірингової діяльності та ліцензії Національного банку України на здійснення окремих банківських операцій у порядку, встановленому Національним банком України;

5) діяльність 3 організації торгівлі на ринку цінних паперів здійснюють фондові біржі;

6) ТIC створюється у формі акціонерного товариства, товариства з обмеженою відповідальністю або у формі дочірнього підприємства об'єднання торговців цінними паперами, що отримало статус СРО та здійснює діяльність з організації торгівлі на позабіржовому ринку й володіє або управляє електронною торговельно-інформаційною мережею;

7) Закон України «Про державне регулювання ринку цінних паперів в Україні» від 30 жовтня 1996 року до надання професійних послуг на вказаному ринку відносить і діяльність з визначення кредитного рейтингу (рейтингування), яка проводиться спеціалізованими організаціями - рейтинговими агентствами. Тобто рейтингові агентства також належать до кола професійних учасників ринку цінних паперів.

Обмеження професійних учасників РЦП лише юридичними особами звужує коло потенційних учасників РЦП, які бажають здійснювати професійну діяльність на РЦП, адже існують і такі види професійної діяльності, що за своєю складністю не вимагають створення юридичної особи. Так, діяльність з управління цінними паперами і комісійну діяльність 3 цінними паперами могли б здійснювати і громадяни-підприємці.

Сьогодні існує необхідність в адаптації законодавства України до законодавства ЄС, процес якої розпочався з набранням чинності Угоди про парт- нерство та співробітництво між Європейськими Співтовариствами та їхніми державами-членами i Україною [6]. Попри велику кількість нормативно-правових актів, прийнятих 3 питань адаптації, у вітчизняній правовій літературі проблеми, пов'язані з адаптацією законодавства України про цінні папери до законодавства ЄС, на жаль, не знайшли значного відображення. Процес адаптації у цій галузі фактично перебуває на початковому етапі. Водночас законодавство ЄС створює всім учасникам майнових відносин рівні права на ринку цінних паперів, у тому числі й фізичним особам.

3 огляду на вищезазначене з метою усунення суперечностей в законодавстві України було б доречним передбачити можливість бути професійними учасниками РЦП і громадянам (фізичним особам), зареєстрованим як суб'єкти підприємницької діяльності.

Грунтуючись на викладеному, пропонуємо на законодавчому рівні закріпити таке визначення. Професійні учасники РЦП - це юридичні особи та/або фізичні особи - суб'єкти підприємницької діяльності, зареєстровані у встановленому законом порядку, які на підставі ліцензії, виданої Національною комісією з цінних паперів та фондового ринку, провадять такі види професійної діяльності: брокерську діяльність, дилерську діяльність, андеррайтинг, діяльність з управління цінними паперами, діяльність 3 управління активами інституційних інвесторів, депозитарну діяльність, діяльність з організації торгівлі, клірингову діяльність, а також володіють спеціальною господарською правосуб'єктністю.

Отже, можна виділити такі основні ознаки професійних учасників РЦП: 1) є суб'єктами господарювання, створеними у встановленому законом порядку; 2) здійснюють певні види професійної діяльності на РЦП на підставі ліцензії НКЦПФР; 3) володіють спеціальною господарською правосуб'єктністю.

\section{Jimepamypa}

1. Господарський кодекс України : Закон України від 16 січня 2003 рок. Голос України. 2003. № 49-50.

2. Цивільний кодекс України : Закон України від 16 січня 2003 року. Відомості Верховної Ради України. 2003. № № 40-44. Ст. 356.

3. Про державне регулювання ринку цінних паперів в Україні : Закон України. Відолості Верховної Ради Украйни. 1996. № 51. Ст. 292.

4. Про цінні папери і фондовий ринок : Закон України від 18 червня 1991 року. Відомості Верховної Ради України. 2006. № 31. Ст. 268.

5. Про фінансові послуги та державне регулювання ринків фінансових послуг : Закон України від 12 липня 2001 року. Відомості Верховної Ради України. 2002. № 1. Ст. 1 .

6. Угода про партнерство та співробітництво між Європейськими Співтовариствами і Україною від 14 червня 1994 року. Бюлетень Міністерства юстииії України. 2001. № 3. С. 194. 
7. Кологойда О.В. Правове регулювання фондового ринку України : навч. посіб. Київ : Юрінком Інтер, 2008. C. 4.

8. Попова А.В. Правове становище професійних учасників ринку цінних паперів в Україні : дис. ... канд. юрид. наук : 12.00 .04 ; Київськ. нац. ун-т ім. Тараса Шевченка. Київ, 2006. 219 с.

9. Панова Л.В. Проблемы правого регулирования рынка ценных бумаг в Украине : дис. ... канд. юрид. наук : 12.00 .03 ; Нац. акад. Украины им. Ярослава Мудрого. Харьков, 2002. С. 65.

\section{Анотація}

Кузнєиова $\boldsymbol{C}$. $A$. Поняття та ознаки професійних учасників ринку цінних паперів в Україні. - Стаття.

Перебудова економіки України супроводжується процесами реформування відносин власності, формування та розвитку повноцінного, ефективного РЦП, який є багатоаспектною соціально-економічною системою, тісно пов'язаною з іншими сферами суспільного життя. Одним із основних інститутів такої системи є професійні учасники РЦП, які мають особливий статус, що пояснюється специфікою виконуваних ними функцій. Професійні учасники є фінансовими посередниками, які за відповідну винагороду перерозподіляють ризики між різними типами інвесторів, а також підвищують ліквідність ринку. Стосовно правового статусу професійних учасників слід підтримати обгрунтовану в юридичній науці позицію, що такі учасники ринку цінних паперів є суб'єктами господарювання. Це стосується всіх категорій професійних учасників вказаного ринку. Діяльність, яку вони провадять на цьому ринку, виступає як діяльність господарська, оскільки вона у повному обсязі охоплюється ознаками цієї діяльності, визначеними у ст. 3 ГК України.

Проблема оцінки фінансово-правового регулювання діяльності професійних учасників РЦП є новою у вітчизняній літературі, оскільки дослідники, зокрема В.В. Колесник, В.С. Торкановський, Ю.М. Лисєнков, Н.В. Фетюхіна, О.Г. Мендул, І.А. Шевчук, Ю.Є. Петруня, у своїх роботах торкаються лише загальної характеристики правового статусу учасників РЦП.

У статті здійснюється аналіз поняття та ознак професійних учасників ринку цінних паперів. Проаналізовано чинне законодавство та погляди науковців щодо тлумачення сутності професійних учасників ринку цінних паперів та внесено власну пропозицію щодо закріплення нового визначення на рівні закону.

Ключові слова: ринок цінних паперів, професійні учасники ринку цінних паперів, торговці цінними паперами, компанія з управління активами інституційних інвесторів, фондова біржа.

\section{Summary}

Kuznietsova Ye. A. The concepts and signs of professional securities market participants in Ukraine. Article.

The restructuring of the Ukrainian economy is accompanied by the processes of reforming property relations, the formation and development of a full-fledged, efficient RPS, which is a multidimensional socio-economic system closely related to other spheres of public life. One of the main institutes of such a system is the professional members of the RCP who have a special status, which is explained by the specificity of their functions. Professional participants are financial intermediaries who redistribute risks between different types of investors and increase market liquidity for an appropriate reward. Concerning the legal status of professional participants, the point of view that such participants in the securities market are economic entities should be supported in legal science. This applies to all, without exception, categories of professional securities market participants. The activity they conduct in this market acts as an economic activity, since it is fully covered by the features of this activity, defined in Art. 3 of the Civil Code of Ukraine.

The problem of estimating the financial and legal regulation of the activities of professional participants of the $\mathrm{RCP}$ is new in the national literature, since researchers, in particular, V.V. Kolesnik, V.S. Torkanovsky, Yu.M. Lysenkov, N.V. Fetyukhina, O.G. Mendul, I.A. Shevchuk, Yu.E. Petrynia. In their works they touch only on the general characteristics of the legal status of participants of the RCP.

In this article the analysis of the notion and characteristics of professional securities market participants, analyzes the current legislation and views of scholars on the interpretation of the essence of professional securities market participants, and makes its own proposal to consolidate the new definition at the law level.

Key words: securities market, professional securities market participants, securities traders, institutional investors asset management company, stock exchange. 